\title{
Matter Flow Through an Animal Model Feed With Grasshopper Sphenarium purpurascens: Evidence of a Sustainable and Nutritious Protein Production System
}

\section{OPEN ACCESS}

Edited by:

John Kinyuru,

Jomo Kenyatta University of Agriculture and Technology, Kenya

Reviewed by:

Sergiy Smetana,

German Institute of Food

Technologies, Germany

Mohammad Mahfujul Haque,

Bangladesh Agricultural

University, Bangladesh

*Correspondence:

René Cerritos

renecerritos@gmail.com

${ }^{\dagger}$ Deceased

Specialty section:

This article was submitted to Climate-Smart Food Systems,

a section of the journal

Frontiers in Sustainable Food Systems

Received: 28 September 2021 Accepted: 18 January 2022

Published: 11 February 2022

Citation:

Meza-Cureño LT, Mendieta

Sánchez AM, Castillo AM, Cabello Hernandez C, Carmona A, Alavez V, Martínez Y, Garcia-Cuenca E,

Cano-Santana $Z$ and Cerritos $R$ (2022) Matter Flow Through an Animal

Model Feed With Grasshopper Sphenarium purpurascens: Evidence of a Sustainable and Nutritious Protein Production System. Front. Sustain. Food Syst. 6:785048. doi: 10.3389/fsufs. 2022.785048

\begin{abstract}
Lluvia Topacio Meza-Cureño ${ }^{1,2}$, Adela Monserrat Mendieta Sánchez ${ }^{1,2}$, Ana Maria Castillo ${ }^{2}$, Christian Cabello Hernandez ${ }^{2}$, Agustin Carmona ${ }^{2}$, Valeria Alavez ${ }^{3,4}$, Yuriana Martínez ${ }^{2}$, Edilberto Garcia-Cuenca ${ }^{1 \dagger}$, Zenón Cano-Santana ${ }^{2}$ and René Cerritos ${ }^{1 *}$

${ }^{1}$ Facultad de Medicina, Centro de Investigación en Politicas, Población y Salud, Universidad Nacional Autónoma de México (UNAM), Mexico City, México, ${ }^{2}$ Facultad de Ciencias, Universidad Nacional Autónoma de México (UNAM), Mexico City,

México, ${ }^{3}$ Posgrado en Ciencias Biológicas, Universidad Nacional Autónoma de México (UNAM), Mexico City, México,

${ }^{4}$ Laboratorio de Genética de la Conservación, Jardín Botánico, Instituto de Biología, Universidad Nacional Autónoma de México (UNAM), Mexico City, México
\end{abstract}

The demand for food and the environmental damage linked to its production will increase significantly; thus, the need for protein sources that are nutritious, digestible, and sustainable in environmental terms is rising. Many bromatological studies show that insects possess high protein amounts, becoming an alternative to conventional livestock. However, in vivo studies on digestibility are scarce (either on humans or laboratory animals), particularly when analyzing assimilation efficiency. In this work, we measured weight gain, food intake, feces and urine quantification, protein assimilation efficiency, and food conversion ratio in Wistar rats fed with five different diets for 5 weeks. Three diets were based on different concentrations of orthopteran protein (Sphenarium purpurascens) and were compared against a control diet and a highly caloric treatment, which was heavy in sugar and refined flours. The diet based on $23 \%$ of S. purpurascens protein resulted in 2.0 and $20.8 \%$ more biomass accumulation than the control and the highly caloric diet, respectively. The diets with $18 \%$ and $23 \%$ insect protein exhibited an average feed conversion of 6.3, while the control group resulted in 8.5 and the caloric diet in 42.7. These results show that $S$. purpurascens protein yields higher or equal conversion values than a conventional diet, indicating that grasshoppers can be a sustainable and nutritious food for humans and an alternative to livestock. On the other hand, even if feeding insects to farm animals for human consumption is considered an option, it seems highly inefficient, mainly because this practice increases one trophic level in the energy flow. Therefore, incorporating insect protein into human diets represents a sustainable alternative to face future feeding and environmental challenges. Proposals like the one we present here have yet to be evaluated; however, our findings in laboratory animals project a promising future for human populations, where low environmental cost proteins could be obtained sustainably.

Keywords: pest arthropods, insects as food, nutritive value, sustainable chance, sustainable protein source 


\section{INTRODUCTION}

In the last four decades, the accelerated population growth and eating habit changes have triggered a significant increase in food production, at least in industrialized countries [Food Agriculture Organization of the United Nations (FAO), 2002]. Vega et al. (2018) suggest a positive correlation between population growth, agricultural production (i.e., corn, wheat, and sugar cane), and non-communicable disease prevalence attributed to highly processed and refined foods. Additionally, the consumption of animal origin protein has increased in recent decades, especially in urban and semi-urban areas, while more sustainable protein sources, such as those of plant origin, have decreased [Food Agriculture Organization of the United Nations (FAOSTAT)., 2017] or have been neglected. Insect species are alternative protein sources of animal origin; their use has been discussed for over 90 years, but it is still underexploited (Yamafuji and Yonezawa, 1935; Bodenheimer, 1951).

With worldwide bovine products expected to double by 2050 (i.e., from 229 to 465 million tons), meeting this demand requires innovative solutions [Food Agriculture Organization of the United Nations (FAO), 2010]. As the market for meat increases, so does the need to feed cattle that eat the same grains as human populations (Pimentel and Pimentel, 2003; Cerritos et al., 2015; Wegier et al., 2018). The livestock sector consumes 6,000 million tons of food annually, including forages, grains, and other materials, comprising a third of the world's cereal production [Food Agriculture Organization of the United Nations (FAO), 2010]. Indeed, large amounts of plant protein are needed to produce an equivalent amount of animal protein in these systems. Pimentel and Pimentel (2003) calculated that cattle consume $\sim 6 \mathrm{~kg}$ of vegetable protein to yield $1 \mathrm{~kg}$ of high-quality animal protein. A typical production system in the United States requires the following amount of food to produce one biomass kilogram: $2.5 \mathrm{~kg}$ for chicken, $5 \mathrm{~kg}$ for pork, and $10 \mathrm{~kg}$ for beef (Smil, 2002). Moreover, agriculture and cattle raising uses $70 \%$ of the freshwater available in the world. Around $30 \%$ of this water is directed to animal production and is responsible for $18 \%$ of greenhouse gas emissions worldwide. In addition, the livestock sector could be the first one responsible for biodiversity loss since it is the first cause of deforestation and has high impacts on soil degradation, pollution, climate change, and spread of invasive alien species (Steinfeld et al., 2009). It is clear that, under current and future protein demands, cattle systems need to be more efficient in producing highly nutritional protein. For example, the common cricket, Acheta domesticus, produces $1 \mathrm{~kg}$ of insect protein by consuming $1.7 \mathrm{~kg}$ of feed (Collavo et al., 2005). However, incorporating insects into the regular diet and reducing meat products, especially beef and pork, is challenging (Wegier et al., 2018).

Around 2,000 edible insect species have been registered worldwide. The Orthoptera is one of the most important orders among them due to its diversity and intensity of exploitation (Cerritos, 2011). The grasshoppers are highly abundant in the agroecosystems, causing millions in economic losses and substantial harvest declines (Samways and Lockwood, 1998; Weiland et al., 2002; Mathew et al., 2009). For example, during 2003-2005 Schistocerca gregaria invasions in Africa, the food security of eight million people was at risk due to the loss of $80-100 \%$ crops (Brader et al., 2005). In Mexico, the cornfield grasshopper (Sphenarium purpurascens) is a pest for agroecosystems, but it is also the primary source of alternative animal-origin proteins (Cerritos and Cano-Santana, 2008). This insect is considered a pest in 16 state provinces of the country [Comité Estatal de S Guanajuato (CESAVEG)., 2010], where it feeds on crops and wild flora foliage in grasslands and in pastures [Instituto Nacional de Investigaciones Forestales Agrícolas y Pecuarias (INIFAP), 2011]. Compared to conventional protein sources, S. purpurascens contains more high-quality protein; for instance, $100 \mathrm{~g}$ of beef contains $\sim 54-57 \%$ protein, while $100 \mathrm{~g}$ of grasshoppers contains 62-75\% (Ramos-Elorduy et al., 1984). Despite these benefits, consumer acceptance remains one of the greatest barriers to adopting insects as a viable protein source in many Western countries. At least in Mexico, grasshoppers' consumption represents a promising food system alternative, not only because of its high nutritional value but also because its production has low environmental costs (Cerritos et al., 2015). Consuming edible pest insects has a double benefit: it will control their population size while providing high-quality protein that could be more accessible and nutritious than conventional sources.

Initially, in Western countries, insects were studied as an option to feed farm animals, especially in the poultry industry (Calvert et al., 1969; Teotia and Miller, 1973; De Foliart et al., 1982; Finke et al., 1985; Nakagaki et al., 1987; Khan, 2018). Calvert et al. (1969) carried out pioneer researches: they fed two groups of birds with diets based on soybeans and Musca domestica pupae and concluded that the insect-based diet might be nutritionally viable for poultry. On the other hand, Finke et al. (1985) fed various groups of chickens with soy-based diets and an alternative based on the Mormon cricket Anabrus simplex, finding no differences between weight gained and food consumed.

Limited studies on insect consumption to explore its implementation in humans have been conducted on laboratory animals as study models (Phelps et al., 1975; Finke et al., 1985; Finke, 2007; Oibiokpa et al., 2018). Analysis of the matter and energy flow from food requires a living system that allows measuring food intake and its proportional distribution into biomass, metabolism, and waste, both in feces and urine (Begon et al., 2006). For this purpose, the laboratory rat is the conventional animal choice. Some characteristics that make it an ideal biological reagent are: (1) small size, which facilitates storage, feed intake quantification, and waste collection; (2) docility if appropriately handled; (3) accessibility; (4) fast growth; and (5) anatomical, physiological, and biochemical similarities with the human digestive system (Kararli, 1995).

Insects could be one of the animal groups with the most significant food potential for human populations. However, they are highly questioned for feeding farm animals, mainly due to the losses in matter and energy inherent to increasing trophic levels (Wegier et al., 2018). Insects have one of the lowest matter conversion rates than other animals used as protein sources (De Foliart, 1997). For example, Oonincx et al. (2015) 
documented obtaining a feed conversion ratio (FCR) of 1.7 in Acheta domesticus under artificial conditions of humidity and temperature. On the other hand, reducing trophic levels for animal protein production decreases environmental problems associated with the agricultural exploitation destined to feed livestock, such as land-use change, water consumption, and pollution (Steinfeld et al., 2009).

In this work, we determined the conversion efficiency of food into biomass, in five groups of Wistar rats fed with different diets: three with varying amounts of $S$. purpurascens protein, a control, and a treatment that resembled an urban Western diet (i.e., based on a minimal protein amount and high caloric content processed and refined flours, sugars, and fats). Afterward, based on our results and a bibliographic review, we reconstructed the accumulated conversion efficiencies of food into biomass from different trophic levels to infer the best protein-obtaining models for human populations. With this study, we aim to promote the incorporation of nutritious and sustainable protein sources because, in the short term, it is imperative that protein-obtaining systems become environmentally sound.

\section{METHODS}

\section{Collection and Processing of Sphenarium purpurascens}

We collected samples of $S$. purpurascens (Orthoptera) in the Puebla-Tlaxcala valley, located at latitude $19^{\circ} 00^{\prime}$ to $19^{\circ} 30^{\prime}$ north and longitude $98^{\circ} 00^{\prime}$ to $98^{\circ} 30^{\prime}$ west. This valley has an agricultural extension of 185,786 ha. There, 40,000-50,000 ha of the corn, alfalfa, and bean crops are infested yearly by this endemic Mexican grasshopper, with an approximate population density of 10-55 individuals per $\mathrm{m}^{2}$.

In October 2018, we collected insects inside crop fields through a mechanical method with striking nets. Then, they were washed and dehydrated. We separated S. purpurascens from other insects and plants with a sieve mesh. Afterwards, we rewashed them to guarantee cleanliness, and through strainers, they were transported to a hot dryer to remove the excess of water in two cycles of $5 \mathrm{~min}$. To cook them, we toasted the grasshoppers on a griddle at $100^{\circ} \mathrm{C}$ for $30 \mathrm{~min}$ until acquiring a reddish color. Finally, we spread them on blankets under the sun, constantly checking and moving them to finish the drying process and preventing decomposition.

\section{Design and Elaboration of Experimental Diets}

We designed four experimental diets (three based on different grasshopper amounts and a hypercaloric treatment with a minimum amount of protein) and a control diet, as follows: (1) standard protein diet (SP): orthopteran protein percentage similar to the nutritional content of commercial food (i.e., Nutricubos authorization SAGARPA A-0207-246 rodent food); (2) hyperproteic diet (HP): orthopteran protein percentage $50 \%$ higher than commercial food; (3) hypoproteic diet (LP): orthopteran protein percentage 50\% lower than commercial food; (4) hypercaloric diet (FF): high in carbohydrates without grasshopper protein and added with highly processed and refined foods and beverages (chicken flavor Maruchan ${ }^{\circledR}$ Ramen noodles and Coca-Cola ${ }^{\circledR}$ soft drink diluted to $50 \%$ with water); and (5) control diet $(\mathrm{CT})$ : based on the commercial food with which rats were feed before starting the experiment (i.e., Nutricubos authorization SAGARPA A-0207-246 rodent food).

SP, HP, and LP contained dry grasshopper flour, dry (nixtamalized) corn flour, dry amaranth grains, unsalted roasted peanuts, and barley flour. We selected these ingredients because all of these are locally produced and are of Mesoamerican origin, except barley. We determined ingredient amounts according to the nutritional characteristics of commercial food (Nutricubos authorization SAGARPA A-0207-246 rodent food) and NOM-062-ZOO-1999 [Secretaría de Agricultura, 2001]. In addition, we obtained nutritional contents from the food composition tables for Central America published by Instituto de Nutrición de Centro América y Panamá (INCAP) y Organización Panamericana de la Salud (OPS) food composition tables (2007), and from by Procuraduría Federal del Consumidor in Mexico [Procuraduria Federal del Consumidor (PROFECO), 2013] for instant soup. For the CT, we used the commercial diet Nutricubos (SAGARPA A-0207-246 rodent food). Total nutritional contents for each treatment are detailed in Table 1.

Pellet production consisted of three stages: ingredient preparation, mixing, and baking at $200^{\circ} \mathrm{C}$ for $20 \mathrm{~min}$, turning them every $10 \mathrm{~min}$. There was additional baking at $180^{\circ} \mathrm{C}$ for $1 \mathrm{~h}$, turning them every $20 \mathrm{~min}$, and finally cooling them on brown paper and storing.

\section{Analyses in Animal Models}

For this study, we used Wistar rats as an animal model. They are normally used in studies on oncology, toxicology, teratogenesis, nutrition, and general purposes [Bioterio de la Universidad Autónoma del Estado de Hidalgo (BUAEH), 2019], have a docile character, and an average of 9.5 offspring. We used 50 male Wistar rats, 2 months old, weighing $\sim 210 \pm 28 \mathrm{~g}$. We separated them into five groups of 10 individuals taken at random. As inclusion parameters, we considered animals without genetic defects or innate diseases. Rats were labeled and housed in groups in polycarbonate boxes with stainless steel grids. They were kept under controlled environmental conditions with cycles of $12 \mathrm{~h}$ light/12 $\mathrm{h}$ darkness, at a temperature from $22 \pm 1^{\circ} \mathrm{C}$ and ad libitum food intake according to the assigned diet.

Animal handling followed the regulations of NOM-062ZOO-1999 [Secretaría de Agricultura, 2001] and international standards for laboratory animals. The Comité Interno para el Cuidado y Uso de Animales de Laboratorio of the Facultad de Medicina, Universidad Nacional Autónoma de México (UNAM) reviewed and approved the procedures we conducted in the animal facility center of the Facultad de Ciencias, UNAM.

\section{Food Intake and Flow of Matter}

Daily, we recorded the food weight per box per treatment between 9 and $10 \mathrm{~h}$. In addition, on a weekly basis, we measured the weight gained per individual in each treatment using a digital kitchen scale ADIR $^{\circledR}$. Similarly, we weighed the faces per box per treatment daily and took a sample of $\sim 50 \mathrm{~g}$ weekly for 
TABLE 1 | Nutritional composition of each treatment (\% in $100 \mathrm{~g}$ of dry processed food).

\begin{tabular}{|c|c|c|c|c|c|c|c|c|}
\hline Diet & & \multicolumn{6}{|c|}{ Ingredients [\%] } & Total [\%] \\
\hline \multirow[t]{3}{*}{ СТ } & Protein & $\mathrm{N} / \mathrm{A}$ & $\mathrm{N} / \mathrm{A}$ & $\mathrm{N} / \mathrm{A}$ & N/A & $N / A$ & N/A & 23.0 \\
\hline & Fat & & & & & & & 3.0 \\
\hline & Ash & & & & & & & 7.0 \\
\hline \multirow[t]{4}{*}{ SP } & Protein & 13.44 & 4.32 & 1.53 & 3.13 & 0.66 & N/A & 23.1 \\
\hline & Fat & 2.34 & 1.75 & 0.69 & 6.57 & 0.08 & & 11.4 \\
\hline & Fibre & 4.21 & 4.44 & 0.98 & 1.06 & 1.03 & & 11.7 \\
\hline & Carbohydrate & 1.11 & 35.31 & 7.00 & 2.85 & 5.14 & & 51.4 \\
\hline & Carbohydrate & 0.59 & 39.39 & 5.29 & 3.63 & 7.70 & & 56.6 \\
\hline & Ash & 0.40 & 0.81 & 0.24 & 0.61 & 0.11 & & 2.2 \\
\hline \multirow[t]{5}{*}{$\mathrm{HP}$} & Protein & 20.71 & 4.07 & 1.11 & 2.44 & 0.36 & N/A & 28.7 \\
\hline & Fat & 3.60 & 1.65 & 0.50 & 5.13 & 0.04 & & 10.9 \\
\hline & Fibre & 6.49 & 4.19 & 0.71 & 0.83 & 0.57 & & 12.8 \\
\hline & Carbohydrate & 1.71 & 33.26 & 5.07 & 2.22 & 2.85 & & 45.1 \\
\hline & Ash & 1.16 & 0.68 & 0.23 & 0.37 & 0.04 & & 2.5 \\
\hline \multirow[t]{3}{*}{$\mathrm{FF}$} & Protein & $\mathrm{N} / \mathrm{A}$ & 4.39 & 1.55 & 3.18 & 0.66 & 2.22 & 12.0 \\
\hline & Fat & & 1.77 & 0.70 & 6.66 & 0.08 & 3.71 & 12.9 \\
\hline & Fibre & & 4.51 & 1.00 & 1.07 & 1.05 & N/D & 7.6 \\
\hline
\end{tabular}

Total and per ingredient nutritional contents are shown for each diet. The ingredient that was substantially changed in each of the experimental diets is distinguished in bold. a Data obtained from Instituto de Nutrición de Centro America (INCAP) y Panamá y Organización Panamericana de la Salud (OPS)., 2007.

${ }^{b}$ Data obtained from Procuraduria Federal del Consumidor PROFECO (2013).

N/A, Not applicable; N/D, No data.

chemical analysis. To determine the energy allocated to metabolic processes, we indirectly recorded the amount of urea excreted from the urine: each week, we took $\sim 50 \mathrm{~g}$ of sawdust impregnated with urine (sawdust was changed daily from the beds in the boxes) and analyzed it by chemical methods. It was impossible to place each of the rats in individual boxes; thus, we averaged the food consumed, feces, and urea by the number of rats in each box and inferred values per individual per box per treatment in grams.

\section{Chemical Analyses}

To determine the amount of urea excreted due to metabolism, we used the Spinreact ${ }^{\circledR}$ Urea L-Q kit, which measures urea concentrations in urine samples by reacting with $\mathrm{o}$ phthalaldehyde in an acid medium and creating a colored complex that can be quantified spectrophotometrically. We put $5 \mathrm{~g}$ of sawdust in tubes with $10 \mathrm{ml}$ of distilled water and let them rest for $30 \mathrm{~min}$. Then, we performed the measurements. To ensure we obtained values due to the urea excreted rather than a biased quantification by the sawdust itself, we took a replica of the same material without rat urine. Then, we recorded the difference between the transmittance of the sawdust from the boxes and the urine-free sample. We measured the transmittance with a Genesys 20 spectrophotometer (Thermo Scientific ${ }^{\circledR}$ ) at a wavelength of $510 \mathrm{~nm}$.

In order to evaluate the amount of protein available in $S$. purpurascens feces, we carried out a bromatological analysis following the Kjeldahl method using $100 \mathrm{~g}$ of matter. We also obtained fat, fiber, and ash percentages. We carried out these analyses in the Laboratorio de Química y Análisis de Alimentos del Departamento de Alimentos y Biotecnología de la Facultad de Química, UNAM.

\section{Calculation of Efficiency Transformations and Data Analyses}

To measure the transformation of food into biomass, we calculated two rates: the feed conversion rate or FCR (Pimentel and Pimentel, 2008) and the protein efficiency ratio or PER 
A

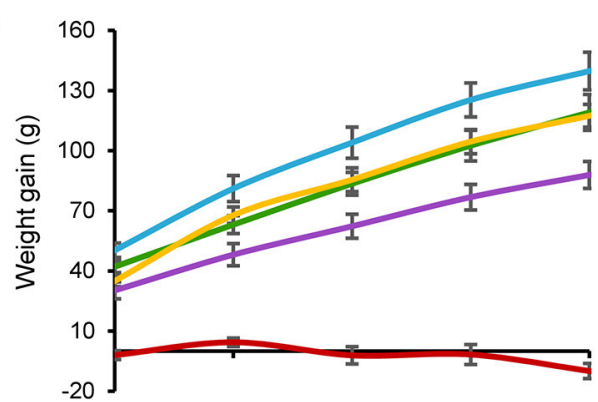

C

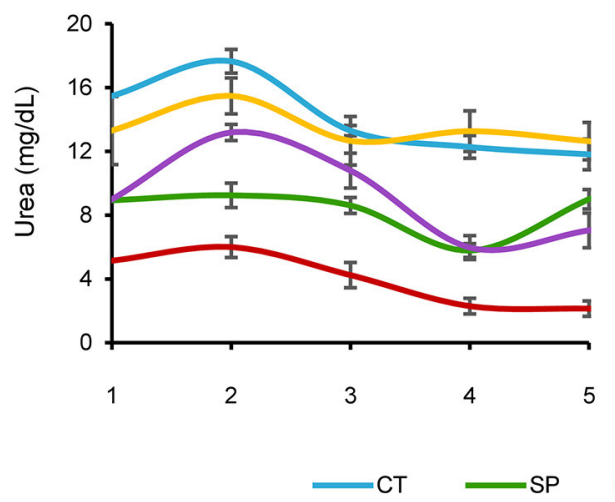

B

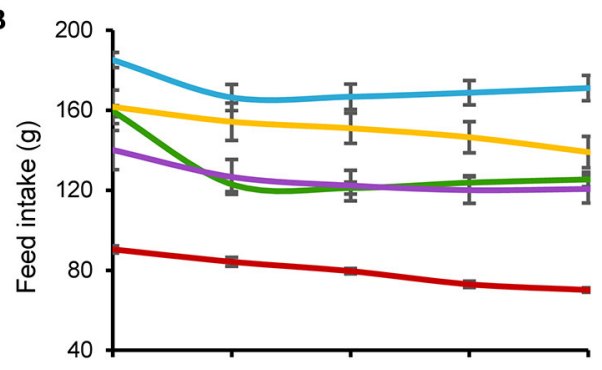

D

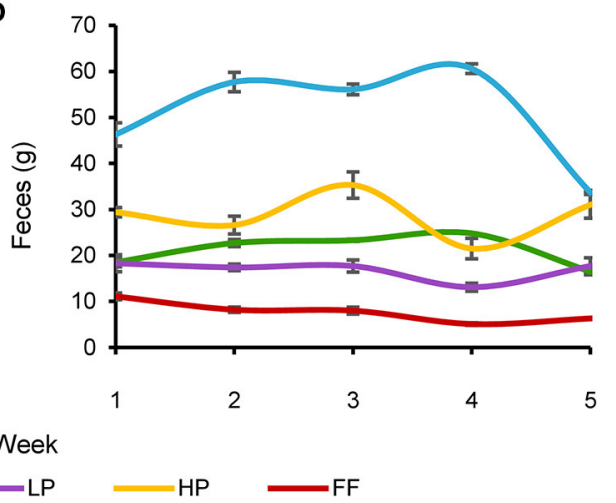

FIGURE 1 | Weekly behavior of different parameters used in each diet: CT, Control; SP, Standard protein; LP, Hypoproteic; HP, Hyperproteic; FF, Hypercaloric. (A) Accumulated weight gain; (B) feed intake; (C) average urea concentration; and (D) feces weight.

[Association of Official analytical Chemists (AOAC)., 1990]. FCR is the ratio of the food intake over the weight gained or lost (Pimentel and Pimentel, 2008). In this case, we took the weight gain or loss and the food consumed per week, per individual, per treatment. PER was calculated under two approaches: (1) PER1 = weight gained $(\mathrm{g}) /$ protein intake $(\mathrm{g})$ and (2) PER2 = weight gained $(\mathrm{g}) /$ food intake $(\mathrm{g}) \times$ protein percentage $(\%)$. To calculate the weight flow per treatment, we applied the equation proposed by Petrusewicz and Macfayden (1970) and Wiegert and Petersen (1983): C $=\mathrm{P}+\mathrm{R}+\mathrm{F}$, where $\mathrm{C}$ is energy consumed, $\mathrm{P}$ is weight stored in the tissues, $\mathrm{R}$ is weight lost by respiration, and $\mathrm{F}$ is weight lost by excretion. We used the urea concentration $(\mathrm{g} / \mathrm{dL})$, obtained from transmittance results and UREA LQ tests (Spinreact ${ }^{\circledR}$ ) to determine $\mathrm{R}$ values. Then, we took the direct measures of weight gain and weekly feces' weight per treatment for $\mathrm{P}$ and $\mathrm{F}$ values, respectively. We analyzed our data for energy flow parameters and conversion rates with repeated measures factorial ANOVA tests and repeated measures ANOVA tests. Normality tests were performed using the Shapiro-Wilk test and Tukey's post-hoc tests, with STATA ${ }^{\circledR}$ statistical software (version 12.0).

\section{RESULTS}

\section{Analyzed Parameters}

Our results indicate a differential response to the experimental treatments in food consumed, weight gained, feces produced, and urea excreted (Figure 1). Within the first 5 weeks of the experiment, the CT group had the highest food intake (171.1 \pm s.e. $1.1 \mathrm{~g})$, while the FF group had the lowest $(79.8 \pm$ s.e. $1.3 \mathrm{~g}$ ) (Figure 1B). Through ANOVA tests, we found significant differences $\left[F_{(16,225)}=4.47, P<0.05\right]$ between $\mathrm{FF}$ and the rest of the groups. There were no differences between SP, HP, and LP groups; however, between LP and CT, we observed marginal differences. Weight gain results showed the same trend: the CT group had the highest accumulated weight with an average value of $139.7 \pm$ s.e. $9.41 \mathrm{~g}$ in 5 weeks, while FF showed weight loss with a cumulative value of $-9.9 \pm$ s.e. $3.78 \mathrm{~g}$ (Figure 1A). SP and HP groups showed a weight gain with an accumulated value of 119.1 and $117.4 \mathrm{~g}$, respectively. ANOVA tests showed significant differences for weight gain $\left[F_{(16,225)}=7.39, P<0.05\right]$ between CT, SP, HP, and LP compared to FF and between CT, SP, and HP compared to LP. The orthoptera-based diets behaved as we expected: the groups with higher food intake gained the most weight; however, although the SP group consumed a greater amount of food than HP (Figures 1A,B), the two diets resulted in almost identical weight gain with no significant differences.

Feces and urea values showed significant differences among some groups. The highest amount of feces was recorded in the CT group, which was significantly different from the other groups, with an average value of $50.9 \pm$ s.e. $1.57 \mathrm{~g}$ (Figure 1D). Meanwhile, within the groups fed with orthoptera-based diets, HP produced a greater amount of stool $(28.8 \pm$ s.e. $1.18 \mathrm{~g})$, significantly different from SP $(21.2 \pm$ s.e. $0.53 \mathrm{~g})$ and LP 


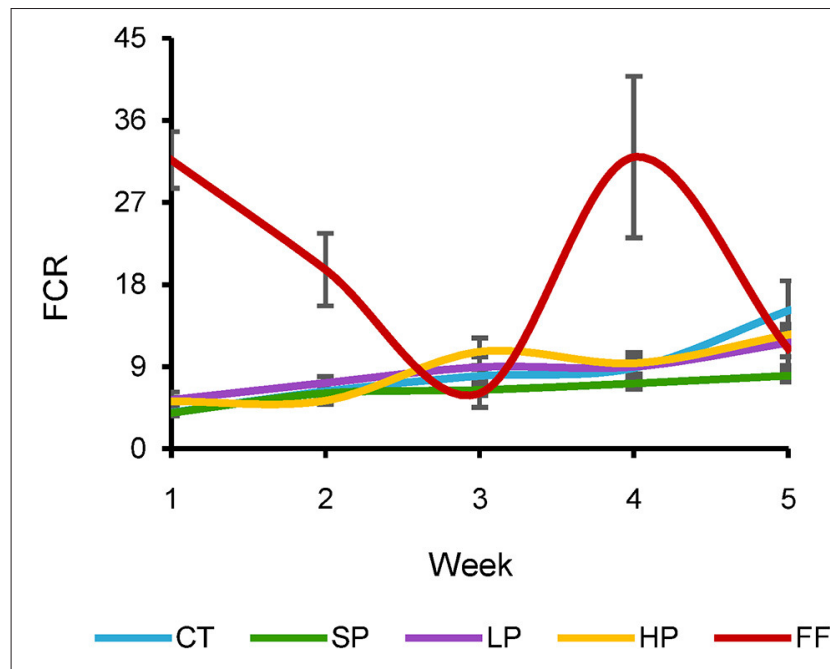

FIGURE 2 | Weekly estimates of Feed Conversion Ratio. Orthopteran-based diet, control diet, and Hypercaloric diet based on refined flours and sugary drinks.

(16.8 \pm s.e. $0.65 \mathrm{~g})$. Again, the FF group exhibited the lowest values, registering $7.7 \pm$ s.e. 0.38 g. Urea concentration in urine showed a different pattern than the parameters mentioned above (Figure 1C): CT, SP, and HP groups excreted a similar weekly concentration of urea $(14.1 \pm$ s.e. $0.4,8.3 \pm$ s.e. 0.3 , and 13.5 \pm s.e. $0.7 \mathrm{mg} / \mathrm{dL}$, respectively), with no significant differences between them. FF registered the lowest urea concentration $(4.0 \pm$ $03 \mathrm{mg} / \mathrm{dL}$ ), significantly different from the remaining four groups $\left[F_{(16,225)}=1.92, P<0.05\right]$.

\section{Parameter Ratios}

The association between food intake and accumulated biomass represents the conversion efficiency of animals fed with different diets. The FCR describes the fraction of food transformed into biomass: values close to 1 indicate the highest efficiency possible. We observed an increasing FCR over time in all treatments except FF (Figure 2). Rats were fed with the three orthoptera-based diets, and the control did not show significant differences between them. For example, CT values shifted from 4.0 to 15.1 in week one and five, respectively, while SP (i.e., a diet with the same protein content as CT but obtained from $S$. purpurascens) ranged from 3.9 to 8.0 for the same weeks, respectively (Figure 2). FF's FCR showed a completely different trend than the other four diets, obtaining values ranging from 31.7 to 11.0. During the 5 weeks, SP obtained the averaged FCR closest to 1 with a value of 6.3 , while CT, LP, and HP obtained values of 8.5, 8.4, and 8.6, respectively (Supplementary Figure 1). Meanwhile, FF resulted in the highest value (20.1) more than an order of magnitude greater than the other groups.

The PER weighs the protein proportion in the food and indicates its effect on each group's growth (Figures 3A,B). As with FCR, we observed considerable differences between weeks within each treatment and found the same trend (i.e., the assimilation rate was more efficient in the last weeks of the experiment in SP, CT, HP, and LP). For instance, in the first week LP obtained a PER value of 4.2 and 1.8 in the last week; CT, SP, and HP values were very similar during the 5 weeks, without significant differences. Although LP showed the best protein efficiency values, there were no significant differences with the other three groups. On the other hand, the FF diet was the least efficient with values of 0.76 and 1.47 for the first and last week, respectively (Figure 3A).

\section{Matter Flow}

Table 2 shows the absolute (in grams) and proportional values of the energy flow parameters (i.e., C, P, R, and F) of the five experimental groups. The proportion destined to accumulate biomass $(P)$ lowest in the FF group $(-0.02)$ and highest in SP (0.18). The other two groups fed with insect protein, LP and $\mathrm{HP}$, were very similar to $\mathrm{CT}$, with proportions ranging from 0.15 to 0.16 . On the other hand, the excreted matter in feces was 0.1 for the FF group and 0.29 for CT, while the grasshopperbased diets exhibited similar values $0.14,0.16$, and 0.18 for the LP, SP, and HP, respectively. Most of the consumed matter was allocated to survival and functioning (i.e., all metabolic processes evidenced through respiration and catabolism products through urine), which is expressed mathematically through the expression $\mathrm{R}=\mathrm{C}+\mathrm{P}+\mathrm{F}$. The group with the highest energy proportion destined metabolic activity was FF with 0.93 , while CT had the lowest proportion with 0.55 . Considering food intake, we would expect CT to have a higher biomass accumulation because it was the group that consumed the largest amount of food (i.e., 8,852.7 g); however, 2,543.9 $\mathrm{g}$ of that matter ended up in waste, which was the largest amount among all groups. Globally, LP had the highest efficiency with 5,981 g of food intake distributed into $879 \mathrm{~g}$ weight gain, $842 \mathrm{~g}$ of waste, and $4,260.1 \mathrm{~g}$ in metabolic activities. Finally, SP had the most efficient ratio considering only its food intake $(6,526 \mathrm{~g})$ and weight gained $(1,191 \mathrm{~g})$.

Based on a literature review and using the FCR values obtained in this work, we constructed weight flow routes through different trophic levels involved in animal protein production. Conventional models have three trophic levels and two weight flows: plants or grains consumed by farm animals and the resulting animal protein consumed by humans. Figure 4 shows that when consuming cow protein, the resulting FCR is 16: 10 from the conversion of plant into animal biomass and 6 from the efficiency or degradation of that protein by humans. In contrast, the cumulative FCR is 7 when consuming insects: 2 from plant to insect and 5 from insect to human.

Models dating back to the 1930s propose feeding insect protein to farm animals. This approach gained much relevance in the last decade. However, Figure $4 \mathrm{~B}$ shows that this production system is highly inefficient, mainly because the matter produced by plants passes through three trophic levels: plant-insectanimal-humans. For instance, in a cattle system, the accumulated FCR is 18: 2 (plant-insect), 10 (insect-cow), and 6 (cow-human). This insect-based system was developed particularly for the avian industry, where organic waste is supposed to be used. However, 

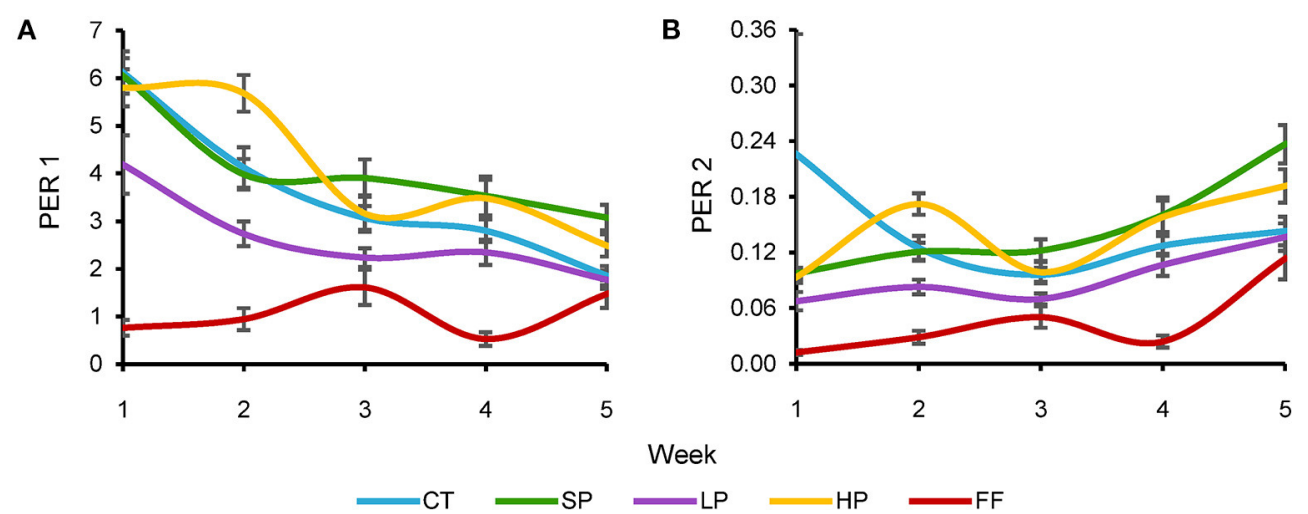

FIGURE 3 | Protein Efficiency Ratios. PER1, (A) = weight gained (g)/protein consumed (g); PER2, (B) = weight gain (g)/food intake (g) $\times$ protein percentage (\%).

TABLE 2 | Estimated values (g) of matter flow parameters for each diet.

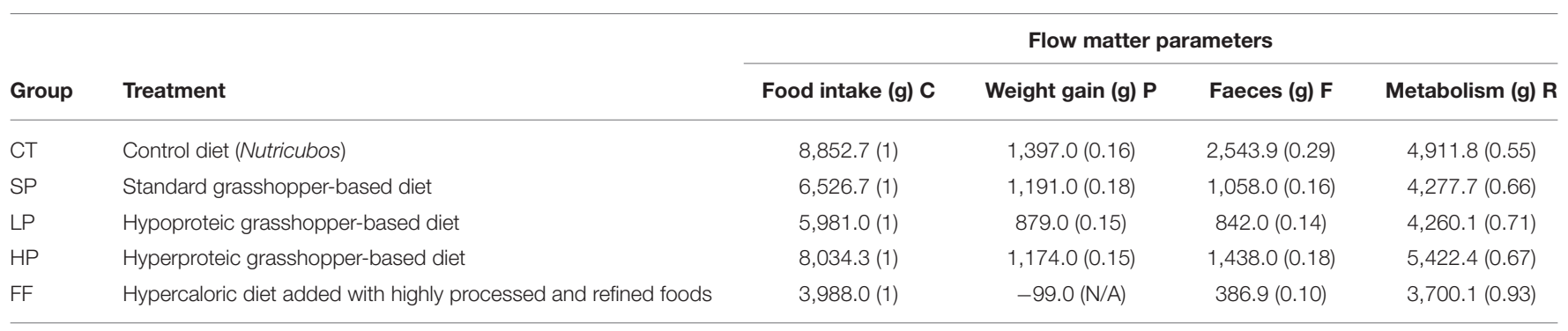

Proportional values are shown in parenthesis following the expression $P+R+F=1$. In general, all treatments invest the highest amount of energy consumed in metabolism. Investment in growth $(P)$ ranges from 0.15 to 0.18 , where $S P$ obtained the highest value.

N/A, Not applicable.

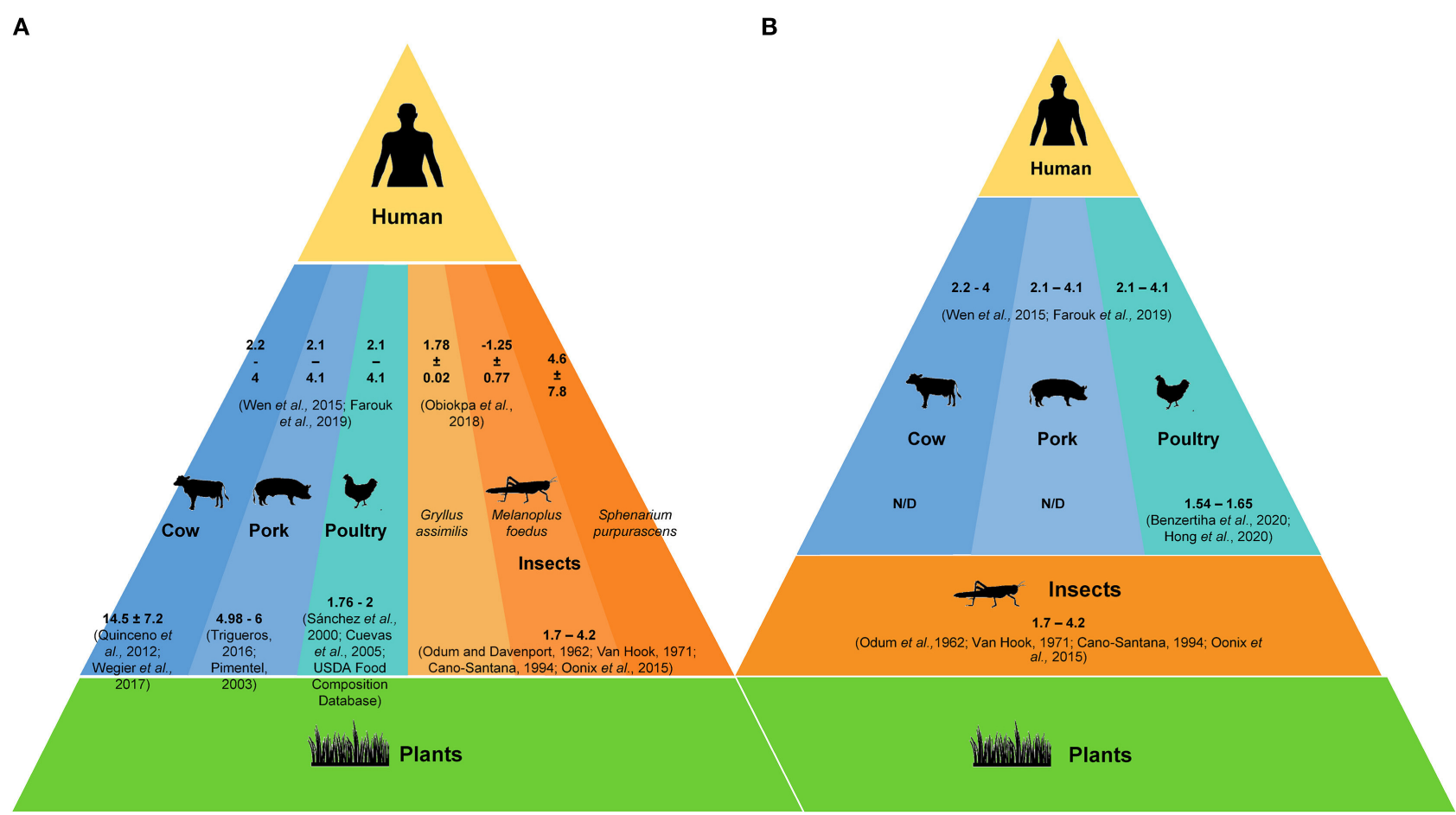

FIGURE 4 | Matter flow between trophic levels in different animal protein production systems: (A) Cumulative FCR values in conventional system with cow, pork, poultry, and insects as protein sources. (B) Cumulative FCR values in systems with an additional trophic level by including insects as food for farm animals. 
the accumulated FCR is 12, which contrasts with the classic system, plant-poultry-human, with a cumulative value of 10 .

\section{DISCUSSION AND CONCLUSION}

For almost 100 years, insects have been proposed as a food source for both farm animals and humans, mainly because of their protein content (Korigawa, 1934; Yamafuji and Yonezawa, 1935). About a decade ago, more benefits of insects as food were described. In addition to their nutritional properties, they are sustainable, especially considering their matter conversion efficiency and low impact on water use and greenhouse gas emissions (Hoekstra and Chapagain, 2006; Oonincx et al., 2010, 2015; Halloran et al., 2016). Moreover, although there is very little work on in vivo digestibility of some insects, there is evidence to support the idea that their proteins are of high quality, due to their amino acid content and concentration (Phelps et al., 1975; Finke et al., 1985; Oibiokpa et al., 2018). Most studies on this subject focus on comparing conventional diets with insectbased diets at different concentrations as an alternative for farm animals, specifically chickens (Calvert et al., 1969; Teotia and Miller, 1973; Finke et al., 1985; Khan, 2018; Filho et al., 2021; Jankowski et al., 2021; Nalunga et al., 2021). In this study, we used Wistar rats as a model to determine the weight flow from feeding them with $S$. purpurascens protein and propose the latter as food for human populations. Our results support the hypothesis that $S$. purpurascens proteins have a similar effect to conventional proteins, as the ratio between weight gain and food intake was similar to that of the control group. Previously, Phelps et al. (1975) conducted one of the first studies on laboratory rats to test the protein assimilation efficiency of the termite species Macrotermes falciger. They found it had higher assimilation than a basal diet but lower assimilation and digestibility when compared to a casein diet. Recently, Oibiokpa et al. (2018) analyzed the protein assimilation efficiency of four insect species and determined that only the common cricket, Acheta domesticus, showed higher values than a casein control diet. The other three species obtained a poor PER (even negative values), mainly due to low food intake. In our study, we expected rats fed with HP to obtain a greater weight gain among the other orthoptera-based diets (SP and LP) and even CT. However, these four groups had similar FCR and PER. Bromatological studies of feces returned contrasting data: the nitrogen amount in $100 \mathrm{~g}$ of HP feces was 61.88 , while in SP and CT, it was 33.59 and 20.63, respectively. Overall, the nitrogen amount in the groups fed with insect protein was higher than CT and FF. This high nitrogen amount in feces may be due to three reasons: (1) the high amount of non-assailable nitrogen contained in insects, particularly in chitin (Díaz-Rojas et al., 2006; Finke, 2007; Langille et al., 2012); (2) the elimination of assailable proteins that are not metabolized due to interference from chitin (Pretorius, 2011; Makkar et al., 2014); and (3) the interaction between two mentioned above.

Recently, several studies have documented that the high nitrogen contents reported in edible arthropods may be nonproteic and indigestible, particularly since the standard method used only can determine total nitrogen amount (Ozimek et al., 1985; Díaz-Rojas et al., 2006; Ghaly and Mahmoud, 2016; Jonas-Levi and Itzhak, 2017). The Kjendhal method used in all conventional bromatological analyses is based on the digestion of organic nitrogen, where the product of the reaction is $\mathrm{NH}_{4}$. At the end of the digestion, total nitrogen is quantified, including chitin and some indigestible proteins (Kirk, 1950). For example, in honey bees, the proportion of chitin is $11 \%$, and this value serves to correct the percentage of raw protein, which is lower by $8.5 \%$ (Ozimek et al., 1985). These works support our assumption that a large part of the raw protein found in rat feces is due to the nitrogen found in chitin.

Even when we found a large amount of raw protein in the feces of rats fed with S. purpurascens protein, we also found better feed and protein conversion efficiencies than other studies with other species. For instance, Calvert et al. (1969) determined FCR values $>6$ in rats fed with the termite $M$. falciger under different concentrations. On the other hand, Oibiokpa et al. (2018), when working with several insect species, found negative FCR and PER values. Only in the case of $A$. domesticus, FCR and PER values were $>5$ and 1.78 , respectively. These values suggest that S. purpurascens contains highly digestible proteins and, therefore, has higher FCR and PER values than other insects, which are just as efficient as other conventional animal protein sources and far superior to a low-protein, highly caloric diet. Additionally, in a parallel study to the one presented here, biochemical and biometric tests revealed that consuming $S$. purpurascens has no adverse effects in laboratory rats (Mendieta et al., in preparation).

In addition, here we show how the energy flow is distributed in our study system. From the food intake in each group, we determined the fraction destined to: (1) accumulate biomass; (2) the maintenance of individuals through their metabolism; and (3) the surplus eliminated in feces. Our results show that most of the energy in all groups allocated to metabolic processes; therefore, our data do not agree with previous reports where most of the energy consumed contributed to animal growth [Clarke et al., 1977; National Research Council United States (NRCUS), 1995]. The total amount of energy is usually partitioned into two components: maintenance and production (i.e., growth, pregnancy, and lactation); thus, animals fed during the maintenance stage are in energy balance, meaning that the metabolizable energy intake keeps the animal at a constant body weight and composition [National Research Council United States (NRCUS), 1995]. The methods we used probably underestimated the fraction destined for maintenance. The residual is the measure that might be better expressing maintenance and growth since it was indirectly determined in two ways: (1) from the subtraction of food intake weight and feces weight, plus the accumulated weight of individuals per unit of time (Uvarov, 1966; Cano-Santana, 1994) and (2) through urea concentration in urine, which would represent the total metabolic activity, including those related to biomass accumulation. The most significant problem in determining the fraction of weight destined to maintenance is isolating it from growth, reproduction, pregnancy, and lactation [National Research Council United States (NRCUS), 1995]. Despite this 
issue, for comparative purposes, we were able to determine two notable behaviors with this experimental design: the three groups fed with orthoptera-based diets were similar to the control group: energy proportions for growth ranged from 0.15 to 0.18 and for maintenance, from 0.54 to 0.71 . Contrastingly, the proportion destined to growth in the FF group was -0.02 and that destined to maintenance was 0.91 ; thus, a diet based on high amounts of sugar, highly processed fats, and low amounts of protein caused malnutrition since rats did not grow and most of the energy was allocated to metabolism.

Undoubtedly, our eating habits and food production systems, both primary and secondary, must be evaluated from nutritional and sustainable perspectives (Castillo et al., 2020). Obtain animal protein, efficiently converting food into body mass (i.e., FCR $\approx 1$ ) and minimizing economic costs, could significantly reduce environmental impact (Cerritos et al., 2015). The food conversion efficiency depends on the species, the diet consumed, and other environmental variables. Due to differences in digestive systems and nutrient requirements, the same diet can result in varying feed conversion efficiencies in different species (Cohen, 2004). This work presents a synthesis of different protein production models, based on conventional animals and S. purpurascens. Previous studies have not simultaneously assessed animal efficiencies to convert food intake (from primary productivity) into biomass and the absorption efficiency of that animal's biomass in human populations. This study attempted to reconstruct this weight flow based on a literature review and our results. Our findings indicate that the poorest accumulated conversion efficiency occurs when a trophic level increases in the protein production systems: nurture insects with crops to feed farm animals that will ultimately feed humans seems even aberrant. Many studies propose that waste from human populations, both organic matter and feces, can be used as food for livestock as a method to recover nutrients (Veldkamp et al., 2012). However, from an ecosystem productivity point of view, these nutrients that Western societies call "waste" actually have energy costs and, above all, environmental costs. Encouraging these types of industries, in the end, would also encourage waste (Cerritos and Klewer, 2015). Conventional production systems, where common farm animals are fed with plant sources, have better efficiency values than the model that aims to increase a trophic level, even compared to cattle with a high average FCR of 10 (Wegier et al., 2018). Multiple works describe that edible insects have a lower FCR than conventional cattle: 3.8 for yellow worms, 4.5 for domestic crickets, 1.7 for Argentine cockroaches, and 1.4 for soldier flies (Oonincx et al., 2015). Even in unconfined environments, Cano-Santana (1994) found that the natural populations of S. purpurascens have FCRs ranging from 2.6 to 3.9. The energy efficiency values from plant sources to $S$. purpurascens are among the better ranked.

As we prove in this study, the assimilation efficiencies of S. purpurascens protein are highly efficient; thus, we may be contemplating one of the most efficient protein production systems on the planet. A previous work projected that about 350 000 tons of this insect could be used annually in a sustainable way in cultivated fields where it is considered a pest: it was determined that in 1,050 000 ha, between 200000 and 500 000 tons per year can be exploited in a sustainable way and with this biomass, almost 9 million people can be fed in a year with a daily serving of 25 grams of protein. (Cerritos et al., 2015). Furthermore, as Mendieta et al. (in preparation) reported, the consumption of this insect does not have any secondary effects in laboratory rats and is very similar in nutritional terms to a conventional protein source. This work is not proposing the expansion of pest insect populations, but rather to use the existing biomass in agrosystems with a high nutritional potential for human populations. Cerritos (2011) proposes differential exploitation plans for endemic and introduced pest insect species: on the one hand, for endemic or native species only a regulation of population sizes should be provided in order to avoid their extinction, while for introduced species their populations should be exploited and eradicated. At a global level, there is a large number of native species of insects that are pests and that can be exploited in a sustainable way (Cerritos, 2011; Wegier et al., 2018). For example, only Cammula pellucida and Melanoplus femurrubrum, which have a wide distribution in North America, could be extracted in millions of hectares within agrosystems (Wegier et al., 2018). Indeed, more studies that can formalize insects as nutritious and sustainable food for humans are lacking as well as adequate information that helps overcome prejudices about these animals. It would seem that we are repeating the history about cereal consumption: in the last century, there were even scientific bases to affirm that wheat was a cereal destined to feed the populations of Anglo-Saxon origin, while corn was a cereal that should feed animals, Afro-Americans, and Indians (Warman, 1995). In the end, it is necessary to prevent the human populations of North America and Europe from using insects to feed livestock and, on the contrary, encourage the consumption of insects as has been done for millennia in regions of Asia, Africa, and Latin America.

\section{DATA AVAILABILITY STATEMENT}

The raw data supporting the conclusions of this article will be made available by the authors, without undue reservation.

\section{ETHICS STATEMENT}

The animal study was reviewed and approved by the Comite Interno para el Cuidado y Uso de Animales de Laboratorio of the Facultad de Medicina, Universidad Nacional Autónoma de México.

\section{AUTHOR CONTRIBUTIONS}

RC conceived and designed the research, analyzed data, interpreted results, and drafted most of the manuscript. LM-C analyzed and interpreted data and drafted additional sections of the manuscript. ACas, AM, VA, ZC-S, and YM analyzed data, revised, and edited the manuscript. CC and ACar contributed to animal experiments. EG-C performed fieldwork and collected grasshoppers. All authors read and approved the final draft. 


\section{FUNDING}

VA is a Ph.D. student from the Posgrado en Ciencias Biológicas, Universidad Nacional Autónoma de México (UNAM) and was supported by CONACYT (scholarship no. 762515).

\section{ACKNOWLEDGMENTS}

We wish to thank the animal facility centre of the Facultad de Ciencias, UNAM, for their support and training in animal handling. Also, we are grateful to Alejandra Ortiz Pérez and

\section{REFERENCES}

Association of Official analytical Chemists (AOAC). (1990). Official Method of Analysis, 15th Edn. Washington DC: AOAC, 771.

Begon, M., Townsend, C. R., and Harper, J. L. (2006). Ecology: From Individuals to Ecosystems. Oxford: Blackwell Publishers, 759.

Benzertiha, A., Kierończyk, B., and Kołodziejski, P. A. Pruszyńska-Oszmałek, E., Rawski, M., Józefiak, D. and Józefiak, A. (2020). Las comidas completas de Tenebrio molitor y Zophobas morio como aditivos alimentarios funcionales afectan el rendimiento del crecimiento de los pollos de engorde y los rasgos del sistema inmunológico. Ciencia Avícola 99, 196-206. doi: 10.3382/ps/pez450

Bioterio de la Universidad Autónoma del Estado de Hidalgo (BUAEH). (2019). Animales de experimentación. Available online at: https://www.uaeh.edu.mx/ bioterio/animales_expe.html (accessed January 11, 2021).

Bodenheimer, F. S. (1951). Insects as Human Food: A Chapter of the Ecology of Man. The Hague: W. Junk Publishers, 352. doi: 10.1007/978-94-017-6159-8_1

Brader, L., Djibo, H., and Faye, F. G. (2005). Towards a More Effective Response to Desert Locusts and Their Impacts on Food Insecurity, Livelihoods and Poverty. Desert Locust Campaign. FAO Programme committee, ninety-sixth session. Food and Agriculture Organization of the United Nations (FAO), Rome, Italy, 21. Available online at: http://www.fao.org/3/j8196e/J8196E.pdf (accessed January 03,2021 ).

Calvert, C. C., Martin, R., and Morgan, N. O. (1969). House fly pupae as food for poultry. J. Econ. Entomol. 62, 938-939. doi: 10.1093/jee/62.4.938

Cano-Santana, Z. (1994). Flujo de energía a través de Sphenarium purpurascens (Orthoptera: Acrididae) y productividad primaria neta aérea en una comunidad xerófita. Universidad Nacional Autónoma de México, Mexico City, Mexico, 198. Available online at: http://132.248.9.195/ptd2014/anteriores/microformas/ 0217751/Index.html (accessed March 22, 2021).

Castillo, A. M., Alavez, V., Castro-Porras, L., Martínez, Y., and Cerritos, F. R. (2020). Analysis of the current agricultural production system, environmental, and health indicators: necessary the rediscovering of the pre-hispanic Mesoamerican diet? Front. Sust. Food Syst. 4, 5. doi: 10.3389/fsufs.2020.00005

Cerritos, R. (2011). Grasshoppers in agrosystems: pest or food? CAB Rev. Perspect. Agric. Vet. Sci. Nutr. Nat. Resour 6, 1-9. doi: 10.1079/PAVSNNR20116017

Cerritos, R., and Cano-Santana, Z. (2008). Harvesting grasshoppers Sphenariumpurpurascens in Mexico for human consumption: A comparison with insecticidal control for managing pest outbreaks. Crop Protect. 27, 473-480. doi: 10.1016/j.cropro.2007.08.001

Cerritos, R., and Klewer, M. (2015). Pre-Hispanic agricultural practices: using pest insects as an alternative source of protein. Anim. Fron. 5, 31-36. doi: 10.2527/af.2015-0017

Cerritos, R., Ponce-Reyes, R., and Rojas García, F. (2015). Exploiting a pest insect species Sphenariumpurpurascens for human consumption: ecological, social, and economic repercussions. J. Insects Food Feed 1, 75-84. doi: 10.3920/JIFF2014.0013

Clarke, H. E., Coates, M., Eva, J. K., Ford, D. J., Milner, C. K., O’Donoghue, P. N., et al. (1977). Dietary standards for laboratory animals: report of the Laboratory Animals Centre Diets Advisory Committee. Lab. Anim. 11, 1-28. doi: $10.1258 / 002367777780959175$

Cohen, A. C. (2004). Insect Diets. Science and Technology. Boca Raton, FL: CRC Press, 324. family García Cuenca, especially to Juana and Celina García, for their support during fieldwork.

\section{SUPPLEMENTARY MATERIAL}

The Supplementary Material for this article can be found online at: https://www.frontiersin.org/articles/10.3389/fsufs. 2022.785048/full\#supplementary-material

Supplementary Figure 1 | Calculation of the food conversion ratio for each diet (CT, Control; SP, Standard protein; LP, Hypoproteic; HP, Hyperproteic; FF, Hypercaloric) at the end of the experiment.

Collavo, A., Glew, R., Huang, Y., Chuang, L., Bosse, R., and Paoletti, M. (2005). "House cricket small-scale farming," in: Ecological Implications of Minilivestock: Role of Insects, Rodents, Frogs and Snails for Sustainable Development, ed M. G. Paoletti (Enfield: Science Publishers), 519-544.

Comité Estatal de S Guanajuato (CESAVEG). (2010). Campaña de manejo fitosanitario de cultivos básicos: Chapulín. Mexico.

Cuevas, A. C., Vega, J. L., and González, E. Á. (2005). Influencia de un estimulante del apetito sobre el consumo de alimento y comportamiento productivo en pollos de engorda. Vet. México 36, 127-133.

De Foliart, G.R. (1997). An overview of the role of edible insects in preserving biodiversity. Ecol. Food Nutr. 36, 109-132. doi: 10.1080/03670244.1997.9991510

De Foliart, G.R., Finke, M.D. and Sunde, M.L. (1982) Potential value of the Mormon cricket (Orthoptera: Tettigoniidae) harvested as a high-protein feed for poultry. J. Econ. Entomol. 75, 848-852. doi: 10.1093/jee/75.5.848

Díaz-Rojas, E. I., Argüelles-Monal, W., Higuera-Ciapara, I., Hernández, J., LizardiMendoza, J., and Goycoolea, F. (2006). Determination of chitin and protein contents during the isolation of chitin from shrimp waste. Macromol. Biosci. 6, 340-347. doi: 10.1002/mabi.200500233

Farouk, M. M., Wu, G., Frost, D. A., Staincliffe, M., and Knowles, S. O. (2019). Factors affecting the digestibility of beef and consequences for designing meat-centric meals. J. Food Qual. 2019:11. doi: 10.1155/2019/2590182

Filho, M. A., Pereira, R., Oliveira, A., Suckeveris, D., Junior, A. B., Soares, C., et al. (2021). Nutritional value of Tenebrio molitor larvae meal for broiler chickens: metabolizable energy and standardized ileal amino acid digestibility. J. Appl. Poultry Res. 30, 100-102. doi: 10.1016/j.japr.2020. 10.001

Finke, M. (2007). Estimate of chitin in raw whole insects. Zoo Biol. 26, 105-15. doi: 10.1002/zoo.20123

Finke, M., Sunde, M., and Defoliart, G. (1985). An evaluation of the protein quality of Mormon crickets (Anabrus simplex Haldeman) when used as a high protein feedstuff for poultry. Poultry Sci. 64, 708-712. doi: 10.3382/ps.0640708

Food and Agriculture Organization of the United Nations (FAO). (2002). The State of Food and Agriculture. Rome, Italy, 22. Available online at: http://www.fao. org/3/y6000en/Y6000EN.pdf (accessed January 11, 2021).

Food and Agriculture Organization of the United Nations (FAO). (2010). Global Livestock Environmental Assessment Model. Available online at: http://www.fao. org/gleam/model-description/en/ (accessed January 26, 2021).

Food and Agriculture Organization of the United Nations (FAOSTAT). (2017). Food Supply Quantity. Available online at: . http://www.fao.org/faostat/en/\# compare (accessed March 27, 2021).

Ghaly, A., and Mahmoud, N. (2016). Effect of the initial $\mathrm{pH}$ on the performance characteristics of the deproteinization process of galactose supplemented shrimp shells by Aspergillus niger in a solid-state drum bioreactor. Int. J. Biotechnol. Mol. Biol. Res. 7, 1-19. doi: 10.5897/IJBMBR2015. 0227

Halloran, A., Roos, N., Eilenberg, J., Cerutti, A., and Bruun, S. (2016). Life cycle assessment of edible insects for food protein: a review. Agron. Sust. Dev. 36, 1-13. doi: 10.1007/s13593-016-0392-8

Hoekstra, A., and Chapagain, A. (2006). Water footprints of nations: water use by people as a function of their consumption pattern. Water Resour. Manag. 21, 35-48. doi: 10.1007/s11269-006-9039-x 
Hong, J., Han, T., and Kim, Y. Y. (2020). Mealworm (Tenebrio molitor Larvae) as an alternative protein source for monogastric animal: A review. Animals 10:2068.

Instituto de Nutrición de Centro America (INCAP) y Panamá y Organización Panamericana de la Salud (OPS). (2007). Tabla de composición de alimentos de Centroamérica. Guatemala: INCAP/OPS, 128. Available online at: http:// www.incap.int/mesocaribefoods/dmdocuments/tablacalimentos.pdf (accessed February 02, 2021).

Instituto Nacional de Investigaciones Forestales Agrícolas y Pecuarias (INIFAP). (2011). Ficha técnica de Chapulín, Brachystola spp. Melanoplus differentialis y Sphenarium purpurascens. México: SAGARPA y SENASICA, 20-28.

Jankowski, J., Kozłowski, K., Zduńczyk, Z., Stepniowska, A., Ognik, K., Kierończyk, B., et al. (2021). The effect of dietary full-fat Hermetiaillucens larvae meal on gut physiology and growth performance in young turkeys. Anim. Feed Sci. Technol. 275, 114879. doi: 10.1016/j.anifeedsci.2021.114879

Jonas-Levi, A., and Itzhak, J. (2017). The high level of protein content reported in insects for food and feed is overestimated. J. Food Compos. Analy. 62, 184-188. doi: 10.1016/j.jfca.2017.06.004

Kararli, T. (1995). Comparison of the gastrointestinal anatomy, physiology, and biochemistry of humans and commonly used laboratory animals. Biopharm. Drug Disposit. 16, 351-80. doi: 10.1002/bdd.2510160502

Khan, S. H. (2018). Recent advances in role of insects as alternative protein source in poultry nutrition. J. Appl. Anim. Res. 46, 1144-1157. doi: 10.1080/09712119.2018.1474743

Kirk, P. L. (1950). Kjeldahl Method for total nitrogen. Analy. Chem. 22, 354-358. doi: $10.1021 /$ ac60038a038

Korigawa, K. (1934). Chemical studies on the locust (1st report), General analysis and protein. ZyozagakuZassi 12, 361-365.

Langille, M. A., Anderson, D., and MacIsaac, J., 2012. Evaluating by-products of the Atlantic shellfish industry as alternative feed ingredients for laying hens. Poultry Sci. 91, 2189-2200. doi: 10.3382/ps.2011-01995

Makkar, H., Tran, G., Heuzé, V., and Ankers, P. (2014). State-of-the-art on use of insects as animal feed. Anim. Feed Sci. Technol. 197, 1-33. doi: 10.1016/j.anifeedsci.2014.07.008

Mathew, L. B., Wyatt, W., and Wright, R. (2009). Degree-Day, Requirements for eight economically important grasshoppers (Orthoptera: Acrididae) in Nebraska using field data. Environ. Entomol. 38, 1521-1526. doi: 10.1603/022.038.0521

Mendieta, S. A., Castillo, N. A., Meza, C. T., Cabello, H. C., Carmona, C. C., Alavez, $\mathrm{V}$, et al. Biochemical and morphometric parameters support nutritional benefits in laboratory rats fed with an orthopteran-based (Sphenarium purpurascens) diet. In process

Nakagaki, B. J., and Sunde, M., and De Foliart, G. (1987). Protein quality of the house cricket, Achetadomesticus, when fed to broiler chicks. Poultry Sci. 66, 1367-1371. doi: 10.3382/ps.0661367

Nalunga, A., Komakech, A. J., Jjagwe, J., Magala, H., and Lederer, J. (2021). Growth characteristics and meat quality of broiler chickens fed earthworm meal from Eudriluseugeniae as a protein source. Livestock Sci. 245, 104394. doi: 10.1016/j.livsci.2021.104394

National Research Council United States (NRCUS). (1995). Nutrient Requirements of Laboratory Animals, $4 h$ Revised Edn. Washington, DC: Subcommittee on Laboratory Animal Nutrition. National Academies Press.

Odum, E. P. Connell, C. E., and Davenport, L.V. (1962). Population energy flow of three primary consumer components of old field ecosystems. Ecology 43, 88-96. doi: $10.2307 / 1932043$

Oibiokpa, F., Akanya, H. O., Jigam, A. A., Saidu, A., and Egwim, E. (2018). Protein quality of four indigenous edible insect species in Nigeria. Food Sci. Hum. Wellness 7, 175-183. doi: 10.1016/j.fshw.2018.05.003

Oonincx, D., Broekhoven, S. V., van Huis, A., and van Loon, J. J. (2015). Feed conversion, survival and development, and composition of four insect species on diets composed of Food By-Products. PLoS ONE 14, 1-20. doi: 10.1371/journal.pone.0144601

Oonincx, D., van Itterbeeck, J., Heetkamp, M., van den Brand, H., van Loon, J., and van Huis, A. (2010). An exploration on greenhouse gas and ammonia production by insect species suitable for animal or human consumption. PLoS ONE, 5, e14445. doi: 10.1371/journal.pone.0014445
Ozimek, L., Sauer, W., Kozikowski, V., Ryan, J. K., Jørgensen, H., and Jelen, P. (1985). Nutritive value of protein extracted from Honey Bees. J. Food Sci. 50 1327-1329. doi: 10.1111/j.1365-2621.1985.tb10469.x

Petrusewicz, K., and Macfayden, A. (1970). Productivity of Terrestrial Animals, Principles and Methods. Oxford: Blackwell Scientific Publisher, 190.

Phelps, R. J., Struthers, J., and Moyo, S. J. L. (1975). Investigations into the nutritive value of MacrotermesFalciger (Isoptera: Termitidae). Zool. Afr. 10, 123-132. doi: 10.1080/00445096.1975.11447501

Pimentel, D., and Pimentel, M. (2003). Sustainability of meat-based and plantbased diets and the environment. Am. J. Clin. Nutr. 78, 660S-663S. doi: 10.1093/ajen/78.3.660S

Pimentel, D., and Pimentel, M. H. (2008). Food, Energy, and Society, 3rd Edn. Boca Raton, FL: CRC Press, 111, 179.

Pretorius, Q. (2011). The Evaluation of Larvae of Musca Domestica (common house fly) as Protein Source for Boiler Production. South Africa: Stellenbosch University, 95. Available online at: https://scholar.sun.ac.za/handle/1009.1/ 46243 (accessed January 10, 2021).

Procuraduria Federal del Consumidor (PROFECO). (2013). “Qué tan buena es tu sopa? Revista del Consumidor 42-55.

Quiceno, J., and Martínez, R., Mateus, H., Gallego J., Medina, P. (2012). Crecimiento en pastoreo rotacional de toretes de razas criollas Romosinuano y Blanco Orejinegro en Colombia. Revista Mvz Córdoba 17, 2891-10, 21897./MVZ.258. doi: 10.21897/rmvz.258

Ramos-Elorduy, J., Pino, J.M., Marquez, C., Rincon, F., Alvarado, M., Escamilla, E, and Bourges, H. (1984). Protein content of some edible insects in Mexico. J. Ethnobiol. 4, 61-72.

Samways, M., and Lockwood, J. (1998). Orthoptera conservation: pests and paradoxes. J. Insect Conserv. 2, 143-149. doi: 10.1023/A:1009652016332

Sánchez, E. R., Barrera, E. M., and González, E. Á. (2000). Evaluación de promotores de crecimiento en pollos de engorda, en un sistema de alimentación restringida y a libre acceso. Vet. México 31, 1-9.

Secretaría de Agricultura, Ganadería, Desarrollo Rural, Pesca y Alimentación (SAGARPA). (2001). Norma Oficial Mexicana NOM-062-Z00-1999, Especificaciones técnicas para la producción, cuidado y uso de los animales de laboratorio. Diario Oficial, 107-165. Available online at: http://publico. senasica.gob. $\mathrm{mx} /$ ? doc $=743$

Smil, V. (2002). Eating meat: evolution, patterns, and consequences. Popul. Dev. Rev. 28, 599-639. doi: 10.1111/j.1728-4457.2002.00599.x

Steinfeld, H., Gerber, P., Wassenaar, T., Castel, V., Rosales, M., and Hann, C. D. (2009). La larga sombra del Ganado: problemas ambientales y opciones. La Iniciativa para Ganadería, Medio Ambiente y Desarrollo (LEAD) and FAO. Rome, Italy, 464. Available online at: http://www.fao.org/3/a0701s/a0701s.pdf (accessed April 14, 2021).

Teotia, J. S., and Miller, B. (1973). Fly pupae as a dietary ingredient for starting chicks. Poultry Sci. 52, 1830-1835. doi: 10.3382/ps.0521830

USDA Food Composition Database. (n.d.). Available online at: https://ndb.nal. usda.gov/ndb/ (accessed January 21, 2021).

Uvarov, B. (1966). Grasshoppers and Locusts. A Handbook of General Acridology. Cambridge: Cambridge University Press, 613.

Van Hook, R. I. Jr. (1971). Energy and nutrient dynamics of spider and orthopteran populations in a grassland ecosystem. Ecol. Monogr. 41, 1-26. doi: $10.2307 / 1942433$

Vega, N. M., Ponce, R. R., Martínez, Y., Carrasco, O. F., and Cerritos, R. (2018). Implications of the western diet for agricultural production, health and climate change. Front. Sust. Food Syst. 2, 88. doi: 10.3389/fsufs.2018.00088

Veldkamp, T., van Duinkerken, G., van Huis, A., Lakemond, C. M. M., Ottevanger, E., Bosch, G., et al. (2012). Insects as a Sustainable Feed Ingredient in Pig and Poultry Diets. A Feasibility Study. Wageningen UR Livestock Research, Report 638. Available online at: https://www.wur.nl/upload_mm/2/8/0/f26765b998b2-49a7-ae43-5251c5b694f6_234247\%5B1\%5D (accessed August 05, 2020).

Warman, A. (1995). La historia de un bastardo: maíz y capitalismo. Fondo de Cultura Económica, Mexico. 283

Wegier, A., Alavez, V., Pérez-López, J., Calzada, L., and Cerritos, R. (2018). Beef or grasshopper hamburgers: the ecological implications of choosing one over the other!. Basic Appl. Ecol. 26, 89-100. doi: 10.1016/j.baae.2017.09.004

Weiland, R., Judge, F., Pels, T., and Grosscurt, A. C. (2002). A literature review and new observations on the use of diflubenzuron for control of locusts 
and grasshoppers throughout the world. World J. Orthoptera Res. 11, 43-54. doi: 10.1665/1082-6467(2002)011[0043:ALRANO]2.0.CO;2

Wen, S., Zhou, G., Song, S., Xu, X., Voglmeir, J., Liu, L., et al. (2015). Discrimination of in vitro and in vivo digestion products of meat proteins from pork, beef, chicken, and fish. Proteomics 15, 3688-3698. doi: 10.1002/pmic.201500179

Wiegert, R. G., and Petersen, C. E. (1983). Energy transfer in insects. Annu. Rev. Entomol. 28, 455-486. doi: 10.1146/annurev.en.28.010183.002323

Yamafuji, I., and Yonezawa, Y. (1935). Enzymes of Bombyxmori. XI. Lipase of the stomach juice. J. Agric. Chem. Soc. Jpn. 11, 77-85. doi: 10.1271/nogeikagaku1924.11.2_77

Conflict of Interest: The authors declare that the research was conducted in the absence of any commercial or financial relationships that could be construed as a potential conflict of interest.
Publisher's Note: All claims expressed in this article are solely those of the authors and do not necessarily represent those of their affiliated organizations, or those of the publisher, the editors and the reviewers. Any product that may be evaluated in this article, or claim that may be made by its manufacturer, is not guaranteed or endorsed by the publisher.

Copyright (๐) 2022 Meza-Cureño, Mendieta Sánchez, Castillo, Cabello Hernandez, Carmona, Alavez, Martinez, Garcia-Cuenca, Cano-Santana and Cerritos. This is an open-access article distributed under the terms of the Creative Commons Attribution License (CC BY). The use, distribution or reproduction in other forums is permitted, provided the original author(s) and the copyright owner(s) are credited and that the original publication in this journal is cited, in accordance with accepted academic practice. No use, distribution or reproduction is permitted which does not comply with these terms. 